\title{
Localized English for Ngapak Javanese Speakers as Language Instruction
}

\author{
Agus Husein As Sabiq \\ IAIN Purwokerto, Central Java, Indonesia \\ husein@iain.purwokerto.ac.id
}

\begin{abstract}
This study aimed to investigate the use of local dialect as language instruction in the English classroom and its demotivating factors for Ngapak Javanese speakers. There were four English teachers and 132 students from four schools in the Ngapak Javanese community participating in this research by semi-structured interviews and questionnaires. The findings showed that local variety influenced students' phonological features, stressing, and intonation. The teachers were indicated having positive attitudes toward the use of local dialect of English. However, they provoked the students to use Bahasa Indonesia as their second language in switching and mixing the code in the teaching and learning process. Lack of vocabulary mastery was also one of the obstacles faced by the teachers. Teachers' perception of the most appropriate implementation of language instruction, teaching strategies, learning resources, and media may lead them to deliver the instruction properly and effectively in improving students' proficiency. Ngapaknese English could be suggested as a pedagogical implication in the sense of Western Central Java because it is more popular, feasible and practical for students. It also has realistic values in classes, including inspiring students to practice speaking, feasible and cost-efficient.
\end{abstract}

Keywords: Ngapaknese English, Language Instruction, World Englishes

\section{INTRODUCTION}

English is considered to be among the most major languages in most countries. There are several causes why English is so crucial to master. One of the causes for this is that English is spoken as the first

ENGLISH FRANCA : Academic Journal of English Language and Education

Vol. 4, No. 2, 2020, IAIN Curup

P-ISSN 2580-3670, E-ISSN 2580-3689

DOI: http://dx.doi.org/10.29240/ef.v4i2.1818, Page 85-114 
language in many countries. And then, it's because of the advanced technology that English is used in our lives. Even in non Englishspeaking countries, people use it for education, tourism, and business. For these purposes, English is used in most countries. In Indonesia, English is taught in most schools, so that anyone can learn English as well as native speakers.

In Indonesia, especially in Java, three great ethnics have greater influential power than others. They are Javanese, Sundanese, and Betawi. But Javanese has the greatest power to influence national socioculture Thus, non-Javanese Indonesians sometimes argue that Javanese imperialism substituted the Dutch version (Anderson \& Keeler, 1988).

Errington (1995, stated in Conners and Klok, 2016) suggested that local vernacular varieties of Indonesian and regional languages have typical connections with close interpersonal interaction in the Indonesian sense. Some regional languages, such as Javanese, have both structured and localized dialects, and these dialects often have typical connections of close social ties but less intense public relations.

Javanese as an Austronesian language family, West Polynesian Malay is one of the regional languages in Indonesia with a large number of speakers. The Javanese language ranks $11^{\text {th }}$ among 6.703 languages in the world for the number of speakers, which is $80-100$ million speakers (Hidayat, 2006). In each region, the Javanese language evolves in accordance with the geographical conditions and conditions of the Javanese speakers themselves, such as the mobility of the population and the communicative relations of the Javanese speakers in the speech area with other speakers in the same speech area. This phenomenon causes Javanese to develop into several dialects. Soedjito points out that the Javanese language has a variety of geographical dialects, such as the Banyumas dialect (Ngapak), Surabaya, Solo, Osing, and Samin (Soedjito, 1986).

Back then, even though English is taught in almost all over the schools in Indonesia, there are some problems for Indonesian people in learning English. One of the problems is because of the poor teaching quality, either with pedagogical knowledge, content knowledge, or both (Rosser, 2018; Zulfikar, 2018). Indonesia has so many different races, 
ethnicities, cultures, languages, and even accents. They are spread out in every district and region. Moreover, there are some Indonesians who only speak with their local languages, such as Ngapak Javanese speakers. There are some of the Ngapak Javanese speakers who can speak Bahasa Indonesia as the national language but not fluently and it is merely used in a formal situation. These must be problems for Ngapak Speakers to learn other languages because they are accustomed to using their first language for daily communication. Language ability can affect by Language Environment (Apriani, 2019).

Almost everyone needs English. English Conversation is one of the activities that students do in their lives (Wardhana, et.al, 2020). Nowadays in Indonesia, most people want to learn English and want to speak English fluently.. In some regencies of Central Java like Banyumas, Kebumen, Cilacap, Banjarnegara, Purbalingga, and Tegal, the majority of the people speak with a bold accent and clear vocal, which is often called "Basa Ngapak" or Ngapak Javanese in which the accent is used in English speech. It is one of the Javanese dialects that has uniqueness in the pronunciation of vocals 'a' being very steady, firm, straight, and not halfcentered. Ngapak dialect speakers amounted to 12 million to 15 million inhabitants. It is just an option whether they should speak other languages with their accent, or speak like English native speakers. Regional language diversity and its dialects will possibly influence English preference as it emphsizes effective communication among the speakers (Y. Kachru, 2008; Tegegne, 2015). For Ngapak Javanese speakers, for example, they will speak Javanese English but using the features of the Western Central Java dialect.

Most of ESL or EFL learners encounter many problems when it comes to learning the target language experienced in both the written and spoken modes. One of the problems is that the learners get to process hard in perceiving different speech sounds from the exposures in a foreign language. Flege (1988) employed the phrase "speech learning" to refer to these processes. Phonological and phonetic influences are reported as sound system problems between L1 and L2 underlining similarities and differences. Thus, the difficulties in perceiving perceptual contrasts between the L1 and L2 are 
characterized as a failure to attend to the phonetic cues for proficient speakers of the L2 (Contreras, 2018).

In Kenya, most of the students have been facing many problems in perceiving the L2 languages due to the mother tongue dialect. The Kenyan learners have the problems in revolving around the place and development of local indigenous languages (Kioko \& Muthwii, 2003). Similarly, Njeru (2013) noted that Kiembu speakers in Kenya have also many phonological errors in writing the words due to the existing difference between English orthography and pronunciation. She said that Kiembu's graphic medium corresponds to Kiembu's pronunciation, which is different from the English pronunciation. In addition, the majority of teachers in Kenya are local speakers of languages. It causes them to experience several problems when teaching the language. Thus, teachers' pedagogical competencies have serious effects on students learning the English language. Non-native teachers of English are shown having problems by making incorrect pronunciation, using first language accent, and lack of requisite skills in English language teaching and learning. Most teachers who teach English for primary school students do not master English skills well and consequently contribute to the perpetuation of English language errors among the learners (Melchers \& Shaw, 2011).

Several studies have been conducted in exploring the effects of Ngapak Javanese in English language acquisition. Purnama (2018) concluded in his research that students' first language affected their English language performance both in oral and written forms. Also, students' environmental background influenced their performances in oral and written English. Gender differences, age, and language choice became other factors in acquiring the English language and performances. Furthermore, Dewi et.al (2017) investigated the effect of Brebes Javanese Dialect (JBD) on students' pronunciation. They concluded that Brebes Javanese Dialect brings a harmful transition toward students' pronunciation on the vowel sound [I], and diphthong [ar], [er], [гә], and[эr]. However, it offers a great transition to the consonant sounds final [d], final [b],and final [g]. But, there is no switch to the initial English cluster/spr/, /str, and//st/. 
Another research was done by Aditriyani (2014) who tried to explore teachers' attitudes towards local varieties of English used by the students in Central Java. She suggested that Javanese English was approved by most of primary schools teachers, although teaching sustainability at higher educational levels remained uncertain. She said that the English varieties used in Indonesia can be Indonesian English, regional English, or localized English. The former is characterized by the impact of Bahasa Indonesia while the second is characterized by the impact of regional languages, and the last is distinguished by the impact of regional dialects.

An investigation into the degree to which junior high school teachers are determined to accept Javanese English as the language instruction in their English classrooms would be valuable. The fundamental focus of this research is to investigate the teachers' attitudes toward the use of local dialect in English classrooms. From this focus, there are also two additional research questions, both are:

a. What are the demotivating factors in teaching English for the students with bold local variety?

b. How suitable is the use of local dialect in English as language instruction in English language teaching for Ngapak Javanese learners?

\section{THEORETICAL FRAMEWORK}

\section{World Englishes}

Since English has become knowns as international or global language, the demand of English makes many researchers interesting to investigate its developments and changes among international communities. As a result, English is used in different styles of Englishes from different communities around the world to communicate (Lee, 2012). Kachru (1992) proposed three concentric cyrcles of Englishusing world, namely inner cyrcle, outer cyrcle, and expanding cyrcle. The Inner Circle belongs to native-English-speaking nations, such as the United Kingdom and New Zealand, which use English as their main language and are either normative or endocentric. The Outer Circle 
contains those countries where English has been distributed as a second language by colonization, such as India, Malaysia, and Zimbabwe. The Expanding Circle includes countries where English is considered a foreign language, such as China, Indonesia, and Thailand. Hence, the term World Englishes is defined as an immersion of varieties of English, especially in non-Western settings, such as the countries in outer cyrcle and expanding cyrcle.

Kirkpatrick (2011) stated that such varieties of English can be easily recognized by its distinctive pronunciation features and vocabulary preferences. Speakers of World Englishes use English in their own ways to express their cultural identities and pragmatic norms (Amalia et al., 2017; Farrell \& Martin, 2009; Kirkpatrick, 2011; Mareva et al., 2016). Malaysian and Singaporean people let the other speakers to know their identities when they use English with their own accents or dialects (Crismore et al., 1996). World Englishes are identically characterized by code-switching and code-mixing (Amalia et al., 2017; Lee, 2012; Li, 2009a; Mareva et al., 2016). This is natural since World Englishes speakers around the world are multilinguals who have learned English as an additional or foreign language. They would naturally switch or mix the codes when talking to other people who have the same linguistic backgrounds. This is an effective way to show a common identity (Kirkpatrick, 2011; Kirkpatrick \& Liddicoat, 2017).

\section{Dialect and Standard English}

It is important to understand what English teachers will do with non-standard dialects used in their classrooms. The English teachers have a lot of expectations from the students. Most significantly, they have standards of the right writing and speaking of their students. This means that it is challenging for students who have a non-standard English accent. According to Holmes (2013), dialect is a collection of speech features that are grouped together and become important for the diversity of each other. Richards (2011) described dialect as a variety of languages used in one region of the country or in people associated with a particular social group that differs from other forms of the same language in some words, grammar and/or pronunciation. Often a dialect 
is synonymous with a particular accent. The status of a dialect is also granted and becomes the standard variety of an area.

On the other hand, Standard English is a type of high variety that is commonly used in newspapers and is spoken by educated people. The distinction between standard and non-standard English is similar to the distinction between formal and vernacular languages (Aitchison \& Wardaugh, 1987). It is important to note that, particularly in the educational context, vernacular dialects are incorrect. They are not linguistic disability. Having a vernacular dialect does not imply that learning a language is bad or imperfect. In schools, students should be encouraged to develop a standard variety of speaking and writing skills but their vernacular dialects reflect the social identification and linguistic knowledge of individuals (Shuchi, 2013).

In reality, teaching Standard English may have negative implications for language learners (Tollefson, 2012). Standard English is a native-speaking paradigm that may be unfeasible for many secondlanguage learners (Cook, 1999). By idealizing Standard English and, subsequently, by devaluing non-standard varieties, some governments and language teachers can actually devalue their own local varieties of English (Farrell \& Martin, 2009).

\section{The Place of Local Dialect in EFL Classroom}

Children typically use their home language to help them communicate what they mean. Besides, the presence of the language of the school allows them to understand the world. The vocabularies of the school are more sophisticated and standardized than the vocabulary spoken at home. However, with a school learning environment, it is important to use language informally. The language could be Standard English, National language, local dialect or an minority ethnic language (Shuchi, 2013). Aimey et al. (2005) found out that many people believe that teaching Standard English is the teacher's duty. They also agree that the use of dialect in the classroom is not acceptable. But in reality, the neglect of dialect in education may have an effect on the lack of cognitive development of some students.

There are some causes in using dialect or Creole in the classroom. There is a connection between standard and non-standard dialects 
because both have rule governed. Besides, if we ignore or refuse homespeaking pupils, this can impair their self-esteem and academic achievement. Each person has his or her own identity and has the right to preserve and grow his or her mother tongue (Aimey et al., 2005). The targeting of native-speaking English skills is not feasible as no research studies have been found to confirm the existence of native-speaking English skills among both second and foreign language learners (Morganna, 2019).

\section{English Local Varieties in Indonesia}

Indonesians use English language according to their linguistic backgrounds (Aziz, 2003; Hamied, 2012; Yuliati, 2014). Several studies have concluded that the discourse features used in articles written by these academics in English and published locally are affected by their linguistic backgrounds (Adityarini, 2014; Aziz, 2003; Safnil, 2013). Moreover, Hamied (2012) claimed that the linguistic characteristics of English local varieties are distinguished by the impact of hundreds of regional languages throughout Indonesia.

Several other studies have concluded that regional languages have an effect on spoken English used by Indonesians (Adityarini, 2014; Dewi et al., 2017; Purnama, 2018). As there a variety of dialects in regional language, the regional language dialect can also affect the English used. A Javanese speaker who speaks a Western Javanese dialect (Basa Ngapak), for instance, can speak Javanese English, but with Western Javanese features. In Indonesia, the English variants may either be Indonesian, regional or a local dialectic variety of English (Amalia et al., 2017). Indonesian English is defined by Bahasa Indonesia's influence, while regional local English varieties have a territorial dialect effect and local dialects characterize their impact on territorial dialects. There is no hypothesis framework at present that fits Indonesia's various dialects.

\section{RESEARCH METHODOLOGY \\ Type of the Research}

This research was categorized as exploratory research that aims to investigate in depth the causes or things that affect the occurrence of 
something and provide a new explanation, discover new ideas, and gain new insight of the target matter or phenomenon (Reiter, 2017; Stebbins, 2012; Swedberg, 2018). This research aimed to explore the form of the problems encountered by the teachers in dealing with dialectical problems in the English classroom and to gain new insight into the use of a local variety of English. The design of research has employed qualitative and quantitative methods that include different research perspectives. For this research, a survey, an observation and a discussion with the teachers were followed by the common collection of data. Books, journals and papers from the library have been selected for the study. Journals and scholarly papers from educational and academic sources have been compiled.

\section{Data Sources}

The data of this research was conducted in 4 junior high schools in Purwokerto and Kebumen Regency. The primary data source of this research is English teachers. They were given questionnaires that they have to give their opinions, perceptions, and suggestions. The subjects of this research are suitable selection because the teachers should face the students' dialectical problems while they teach English. The secondary data source was gathered from classroom observation to conduct the teachers' treatments dealing with students' dialectical problems that occurred in English language teaching.

\section{Techniques and Instruments of Data Collection}

In gathering the data in this research, it used some techniques and instruments. They were:

\section{Observation}

The instruments of direct observation were the form of observation sheet and field notes which are used to record what happened in the classroom. These instruments were also used to observe the teachers' treatments, language instruction, media, and resources dealing with students' dialectical problems that occurred in English language teaching.

Semi-structured Interview 
A semi-structured interview is conveyed by delivering a list of questions in the interview guideline, but there is flexibility when and how the questions are asked and how the respondents to answer (Edwards \& Holland, 2013). In this study, the interview was delivered to both the teachers and students. It was used to figure out what the students feel in the English teaching learning process especially in speaking and pronouncing English words. Besides, it was used to find out the problems that the students face in undergoing the teaching and learning process. Also, interviews were used to find out the information on the teachers' attitudes toward students' dialect, their perceptions about the use of local dialect in English, and their treatments dealing with students' dialectical problems.

\section{Questionnaire}

Like the interview, the questionnaire was used to gather the data of the teachers' opinions and suggestions deal with dialectical problems in English. The questionnaire items consisted of 2 questions for personal information of the respondents, 15 multiple-choice questions and 1 open-ended question on attitudes towards the local dialect., attitudes towards students' dialectical problems, and the improvement of ELT for Ngapak Javanese speakers.

Data analysis techniques in this research used four stages. Those are assembling the data, coding the data, comparing the data, and building interpretation (Patton, 1990). The researcher used triangulation technique to compare the results of observation, interviews, and questionnaires to make the data gathered valid and prevent misinterpretation.

\section{FINDINGS ANDDISCUSSION}

\section{Findings}

\section{Participants Description}

In this research, there were four teachers participated in conducting the research data. They were from SMP PGRI Kuwarasan (teacher 1), SMP Ma'arif Kuwarasan (teacher 2), SMPN 1 Buayan (teacher 3), and SMP PGRI Buayan (teacher 4). All of the teachers have 
been teaching for more than 8 years. They all graduated from the English Department from various universities in Central Java. All of them also have English class in grade eight with 2 meetings per week. Besides the teachers, there were also eight students from 4 schools that have been interviewed. In doing observation, the researcher observed four classes from four schools which consisted of 124 students. All of the students were from $8^{\text {th }}$ grade.

\section{Teaching experiences}

The results of the interview and questionnaire indicated that the teachers from four schools had been teaching for more than 5 years. The youngest teacher was the teacher from SMP Ma'arif Kuwarasan who had been teaching for 8 years, and the teacher from SMP PGRI Buayan had the longest experience of becoming an English teacher because she started in 1999. It has been 19 years. Also, they all graduated from the English Department from various universities in Java. No teacher graduated from a magister degree. However, they all have ever followed some of the teacher training held by the Ministry of Education or the Ministry of Religion.

\section{Teachers' Perceptions toward TEFL in Indonesia}

The teachers had various perceptions about the use of English in Indonesian daily activities. Generally, they said that English is used in narrow scope such as in the academic field. They thought that the difficulties of learning English were influenced by no use in daily communication. In the Indonesian context, they all said that English could be better used in education, media promotion, and business. The following chart described the teachers' perceptions of the use of English in the Indonesian context.

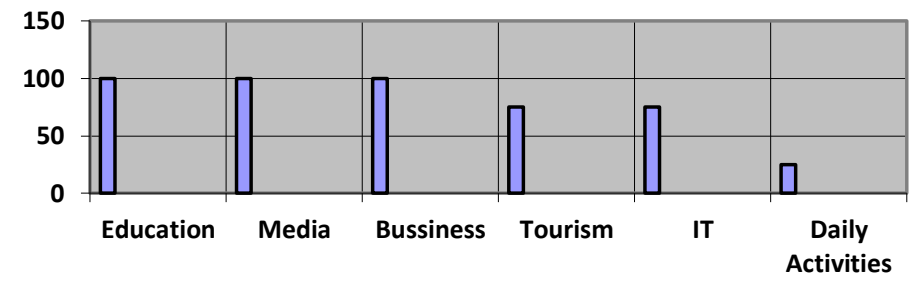

Figure 1. Teachers' perception of the use of English in the Indonesian context 
They realized that English was used by the students only when they were in school especially in English class, so they did not expect too high to students' mastery of English in which they lived in a rural area. It was proved from the result of the questionnaire that half of them thought that English is not really very important in Indonesia. In the context of English as a global language, half of them thought that English in Indonesia is an as third or additional language, one of them said that English is a second language, and the other one said English as a foreign language. They all felt that teaching English for Indonesian students is different from teaching English in neighbor countries like Malaysia, Singapura, etc. that used English as a second language. However, they believed that the English used in Indonesia should be strengthened and not relegated to the context. As Mrs. Nunik said:

Researcher : What do you think about the use of English is the same with which is used in our neighbor countries such as Malaysia, Singapore, Australia, etc.?

Teacher $2 \quad$ : I think it's quite different. English in those countries used in daily activities, but in Indonesia, English is only used in the learning field.

\section{Regional Form in ELT Process}

In conducting this research, the use of regional form (in the dialect and the grammar) in English language teaching was the focus of the research. Thus, the teachers were asked about it. The teachers answered that the use of the first language made mixed code in communication. The clear influence was in pronouncing the words. They quietly agreed that they can't avoid the use of the first language in their English language teaching. They also believed that forms (in the dialect and the grammatical features) of English used by Indonesian people are generally influenced by their regional languages (local dialect).

In the form of regional dialect, in this case, it was Ngapak dialect; the teachers said that the Ngapak dialect was a kind of Javanese dialect that had its characteristics. They were born and grew up in Ngapak dialect's families and community and so did the students. They realized that the Ngapak dialect was a local bold accent of the Javanese language. 
Ngapak Javanese speakers would read English words in the way it was written. So, based on the teachers' opinions, the accent or dialect will affect the students' pronunciation. But honestly, the teacher considered that problem. They thought that there is no matter the dialect used by the students while using English as long as it is understandable. They concerned about meaning delivered by the students not the ways they used the language. However, they agreed to encourage their students to use English in the way they like to do considering the language they use in their daily lives.

In the English teaching and learning process, the teachers were asked about their students' preferences in using the language. They dealt that most of the students still used their first language i.e. Ngapak Javanese although the teachers always ask them to use Bahasa Indonesia if they do not know how to say in English. Whenever the students used their mother tongues, the teachers would lead them to use Bahasa Indonesia rather than Ngapak Javanese. The teachers seemed no matter about mixing code with the students' mother tongues or Bahasa Indonesia. However, the teachers said that the intensity of the use of the Ngapak Javanese dialect might influence the students' English mastery, especially in pronunciation. Based on their opinions, Ngapak Javanese has a thick and clear stressing and intonation, especially in the last syllable. So, generally, the students were influenced by the thick pronunciation, stressing, and intonation.

The researcher then tried to get deeper information about using English through the Ngapak Javanese dialect. The researcher found that the teachers did not matter with speaking English using the Ngapak Javanese dialect for the beginners as long as the students were easy to understand the target language.

Researcher : What do you think of speaking English using the Basa Ngapak dialect?

Teacher $1 \quad$ : I think it is good and no matter to be applied.

The idea of English speaking based on the environmental context around the students' backgrounds like using the Ngapak Javanese dialect (Ngapaknese English) was also asked for the teachers. They felt it 
could be applied because it was sound good and unique. As a matter of fact, they were no problem to teach English using Ngapak Javanese dialect for global communication. The use of Ngapak Javanese in speaking English would become a problem when the listener failed to understand and confused in listening to the Ngapak Javanese dialect. Besides, the students' intensities in using the Ngapak Javanese dialect would give them a big problem when they meet the native speakers.

Another problem faced by the teachers in teaching English for Ngapak Javanese students was vocabulary mastery. The different ways of reading the English written text made the students difficult in memorizing and acquiring new words in English.

Researcher : Do you feel difficulty to speak English? Why?

Student $3 \quad$ :It is difficult for me because I haven't no much vocabularies and its pronunciation is also quite difficult.

As long as the interview, the teachers were asked about the solution done to solve the problems they faced. Almost all of the teachers answered that the drilling technique became the most appropriate way to deal with the students' lack of pronunciation and vocabulary. Besides, the teachers also used the audiovisual media such as video to reinforce the instruction in the classroom activities.

Researcher : : Is there any specific learning media you used to improve learning activities?

Teacher 3 : I use a video of a native speaker.

As a result of the questionnaire, the teachers were asked to choose the most appropriate teaching activities that were best applied to teach English for Ngapak Javanese speakers. They believe that teaching English for Ngapak Javanese speakers could be implemented in the following teaching activities such as translation, repetition, playing games, building sentences, retelling. On the other hand, activities such as memorization, role plays, reports, interviews, and singing, were indicated to be valuable use in the English classroom.

In taking the advantages of learning resources, the teachers strongly agreed with the use of games, traditional games, traditional clothes, traditional songs, traditional music, quizzes, dolls, gifts, movies, 
short stories, and CDs. Those resources were indicated as easy to use and find. The available learning resources became a challenge for the teachers in the rural area to deliver the learning materials in their classrooms. They would prefer to choose the easy use of resources.

Relating to professional competence development, the teachers pointed out that the engagement of the government in developing teachers' competences was very important. By providing workshops, seminars, and training sessions, the teachers could improve their teaching styles and be expected to solve the problems they face in the teaching and learning process effectively. Besides the availability of teachers' professional development, the teachers believed that the government should only permit English-based teachers to teach English, especially in high school levels.

The last question was about teachers' opinions in using local language to teach English forms or rules. They strongly disagreed if the use of local dialect applied in teaching English. They encouraged the students to use Bahasa Indonesia to become the first language in the classroom rather than the local language. But, they tolerated the use of local dialect in speaking English. They thought that language is for communication, as long as the speaker and the listener understand each other speech, it was no problem with the dialect used.

\section{Discussion}

\section{Teachers' Attitudes toward the Use of Local Dialect}

The use of local varieties of English was considered as evidence of different phonological features between L1 and English. It was influenced by regional languages used by the speakers. The English teachers were indicated having positive attitudes on the use of local dialect in English speech. The teachers had a good understanding of the position of English in the Indonesian context. English is not used in daily communication in the community. It is used in limited areas of the teachers' and students' lives. Understanding the position of English in the community would become the basic consideration of designing learning activities including providing learning resources, teaching media, and applying the most appropriate teaching strategies. 
The teachers' treatments toward the students learning process should also consider the students' environmental backgrounds. The language they use daily would affect the proficiency of the target language. So, in the English classroom, the use of the first language or even the local language may occur in the process. The teachers should be wise in dealing with this matter in order to provide comprehensible input for their students.

From the data presented, the students sometimes used their local language when they did not know how to say in English. The teachers' responses in figuring this out were indicated in the right ways by encouraging the students to use Bahasa Indonesia rather than the local language, in this case, it was Basa Ngapak. Although the teachers provoked the students to prefer Bahasa Indonesia which was indicated as their second language, the teachers did not concern with the dialect used in speaking English. For the teachers, it was acceptable as long as it was still understandable. Besides, the teachers concerned with the meaning, not the form (dialect and rule). As Bernhardt \& Krashen (1989) said that to provide language acquisition, the speakers are not concerned with the rules or forms of their utterances but with their messages they express and understand. In real communication, the extensive use of grammatical rules and standards to be native-like speakers can minimize comprehensible input that the students will have anxiety conditions (Krashen, 2013).

As members of multilingual communities, the participants were truly aware of the context where they live. As a matter of fact, there are more than 700 regional languages in Indonesia (Andy Kirkpatrick \& Liddicoat, 2017). In daily communication, Most Indonesians speak with their local language as their first language both in family and community. They will only use Bahasa Indonesia as the national language in a formal situation (Dardjowidjojo, 2000). Eventually, their English would be influenced by their first and second languages (Aziz, 2003; Dewi et al., 2017).

In essence, Bahasa Indonesia is the Indonesian people's lingua franca. While the participants expressed their favorable attitude to their local English varieties, they found that localized English uses by students 
can not be understandable to interact with other people who speak a different English variety (Adityarini, 2014). Therefore, when the students switch the code in the teaching and learning process, the teachers provoked them to use a second language i.e Bahasa Indonesia, not their first language.

The issue of intelligibility was also found by Li (2009) that most of the participants in his research did not prefer a localized English accent because of intelligibility. He reported that Chinese university students caught in a dilemma between keeping their identity by using their local English and concerning their intelligibility (Li, 2009b). Similarly, Belibi (2013) also found the dilemmatic problems in his research to Cameroon English teachers. To apply a local variety of English, there should be a comprehensive basis on the perception, acceptance, and pedagogical implication (R. Belibi, 2013). On the other hand, localized English was reported internationally intelligible according to the teachers from two Outer Circle groups, Nigeria and Malaysia (Crismore et al., 1996; Olatunji, 2012).

\section{Demotivating Factors on Teaching English for Ngapak Javanese Speakers}

Teaching English toward students with a bold local accent was quite challenging if it could not be said as hard. Every language has its characteristics in pronouncing, stressing, sound system, and intonation. The results of several studies showed that Indonesian students faced some problems in pronouncing English words because of different phonological, phonemic, and phonetic features (Andi-Pallawa \& Fiptar Abdi Alam, 2013; Komariah, 2018; Kosasih, 2017; Pranowo, 2006; Tiono \& Yosta, 2008). Besides pronunciation, the students' motivation toward English and English language teaching were indicated as one of the influencing factors toward students' achievements in English (As Sabiq, 2018; Fadillah, 2014; Ozen, 2017; Subandowo, 2017; Yulika et al., 2019).

As a matter of fact, the teachers had hardly tried to teach English as it is. They had minimalized the students' errors in pronouncing the English words to not become fossilized by giving feedbacks on error correction (Marefat \& Nushi, 2012; Pranita, 2014; Thornbury, 2013). 
The teachers also let the students speak as much as they can without avoiding the dialect the students used in speaking.

Lack of vocabulary mastery was also one of the obstacles faced by the teachers. It was understandable that the students felt difficult to pronounce, so their attitudes toward vocabulary mastery were reduced. Teachers' perception of the most appropriate application of learning strategies, resources, and media may lead them to deliver the instruction properly and effectively in improving students' vocabulary.

Engaging local culture in the teaching and learning process as a benchmark would make appropriate learning strategies. Through intercultural communication, the teachers can provide the materials in which those are acceptable and not acceptable based on their local culture (Sabiq et al., 2019; Subandowo, 2017). The teachers were also challenged to choose effective learning resources. Some research has shown that many local English textbooks have already included elements of local cultures known by the students in primary schools. (Prastiwi, 2013; Sudartini, 2012; Syahri \& Susanti, 2016).

\section{Localized English as Language Instruction}

The participants were indicated having positive attitudes toward the adoption of local dialect in English because of several factors. First, they realized that learning English as a global language is very important, but on the other hand, their own identities were also important to maintain. This was seen from their perception of ELT based on the local context. Moreover, the students will have the best learning outcomes in learning engagement and easy to understand the linguistic form different cultural practice through the insertion of local culture expression (Adityarini, 2014; Cohn \& Ravindranath, 2014; Friedlander, 2011).

Second, the participants taught that the use of localized English makes them easy to provide comprehensible input, interesting learning, and suitable for the students' linguistic backgrounds. The use of L1 or local variety in English classrooms becomes debatable nowadays. However, the notion of the use of a particular variety of English, e.g. Javanese English or Ngapaknese English, was considered to make the students aware of the differences and similarities between their 
language and English. Also, it can be accommodated as the tool for the teachers to clarify the difficult word, motivate them to speak more, teach grammar, and explain new vocabulary (Adityarini, 2014; Inal \& Turhanl, 2005).

Third, the severity of Javanese English usage is most likely to reinforce the local identity of the Javanese people that the more generic Indonesian English could not achieve (Andriyanti, 2019; Friedlander, 2011; Suharsih, 2017; Sukarno, 2010). This possibility is assumed that Bahasa Indonesia is "not an identity marker in the same way that a first language might be assumed to be" (Lamb \& Coleman, 2008; Suharsih, 2017). Furthermore, Moedjito also found that Indonesian English was the least preference by English teachers to become an appropriate model in teaching English for lower secondary schools in West Nusa Tenggara province because of Bahasa Indonesia, which is characterized Indonesian English, was their L2 (Moedjito, 2008).

Ngapak Javanese has unique features that differentiate it with the Central Javanese dialect, for example, the vowel /a/ which is pronounced very steady, firmly, straightly, and bold and the presence of sound / $/$ or / $/$ at the end of the vowels (Dewi et al., 2017; Purnama, 2018). The reason why people prefer to use their language rather than English in the EFL classroom is that it reflects their beliefs, assumption, needs, and desire (Pablo et al., 2011). The teachers considered that Basa Ngapak's phonemic features could be seen as features that help students understand English better. For Ngapak Javanese speakers, their Javanese language seems to more closely link to their region than the Java region, since the Javanese language refers their identity (Dewi et al., 2017).

There is a disagreement between researchers about the recognition of a local diversity of English. Although this research found the appropriateness with the previous studies, there are some studies concluded contrasty. Chan and Evans found that the attitude of secondary school students in Hong-Kong toward Hong-Kong English (HKE) was reported negative as a variety of English and therefore an acceptable model in the local ELT classrooms for pronunciation (Chan \& Evans, 2011). Similarly, Mareva et.al investigated ESL teachers in emerging local varieties of English in Zimbabwe. the participants said 
that although there was no wrong in using local varieties in English classrooms, the teachers preferred using standard English as the norms of teaching English (Mareva et al., 2016).

\section{CONCLUSION}

Teachers' perception of the most appropriate implementation of language instruction, teaching strategies, learning resources, and media may lead them to deliver the instruction properly and effectively in improving students' English proficiency. The idea of Javanese English could be developed as World Englishes in which there are about 80 million Javanese speakers or $40 \%$ of Indonesia's population. In the narrower scope of Javanese English, Ngapaknese English would also acceptable to become a pedagogical implication in the Western Central Java context because it is more popular, feasible and practical for students. It also has realistic values in classes, including inspiring students to practice speaking, feasible and cost-efficient. Ngapaknese English could be considered as a pedagogical implication in the Western Central Java context (Ngapak Javanese community) for some reason. First, Ngapaknese English represents the speakers' identity. Second, there are educated Javanese speakers who are internationally intelligible who have already been modeled. Third, Ngapaknese English for Ngapak Javanese students is more popular, accessible, and practical. Finally, the advancement of Ngapaknese English in Western Central Java as the ELT language instruction, because of local sources and resources, is feasible and cost-efficient. It is different from the adoption of exonormative models in which the students should buy imported books from native speakers.

\section{REFERENCES}

Adityarini, H. (2014). An Examination of the Suitability of a Pluricentric Model of English Language Teaching for Primary Education in Indonesia Hepy Adityarini (Issue August). http://hdl.handle.net/20.500.11937/1337 
Aimey, O., Francis, G., \& Soyer, S. (2005). Kaleidoscope Teacher's guide Tour. In Ginn and Company. Harcourt Education Limited. https://books.google.com.bd/books?id=ekRJ3RIPBJoC\&pg=PA6\&d $\mathrm{q}=$ dialect+and+cognitive+development\&hl=en\&sa=X\&ei=jH7VUYvs AcfLrQe114C4DQ\&redir_esc=y\#v=onepage \&q=dialect and cognitive development\&f=false

Aitchison, J., \& Wardaugh, R. (1987). An Introduction to Sociolinguistics. The British Journal of Sociology, 38(3), 436. https://doi.org/10.2307/590702

Amalia, S. D., Laila, M., \& Adityarini, H. (2017). The Place of Javanese English Among Globally Known Varieties of World Englishes. 123128.

http://journal.ummgl.ac.id/index.php/urecol/article/view/1181

Anderson, B. R., \& Keeler, W. (1988). Javanese Shadow Plays, Javanese Selves. World Literature Today. https://doi.org/10.2307/40143761

Andi-Pallawa, B., \& Fiptar Abdi Alam, A. (2013). A Comparative Analysis between English and Indonesian Phonological Systems. International Journal of English Language Education, 1(3). https://doi.org/10.5296/ijele.v1i3.3892

Andriyanti, E. (2019). Language Shift among Javanese Youth and Their Perception of Local and National Identities. GEMA Online® Journal of Language Studies. https://doi.org/10.17576/gema-2019-190307

Apriani, E., Anshori, S., \& Edy, S. (2019). Eksistensi English Zone Sebagai Media Penerapan Kemampuan Berbahasa Inggris Mahasiswa Program Studi Tadris Bahasa Inggris IAIN CURUP. Cendekia: Jurnal Kependidikan Dan Kemasyarakatan, 17(2), 317-332.

As Sabiq, A. H. (2018). Improving Students' Motivation and Reading Skills in ELT through Audio Visual Media. Diksi, 25(1), 57-68. https://doi.org/10.21831/diksi.v25i1.16007

Aziz, E. (2003). Indonesian English: what's det tuh? TEFLIN Journal, 14(1), 140-149. 
https://doi.org/http://dx.doi.org/10.15639/teflinjournal.v14i1/14 $0-148$

Bernhardt, E. B., \& Krashen, S. D. (1989). Second Language Acquisition and Second Language Learning. The Modern Language Journal. https://doi.org/10.2307/326882

Chan, J. Y. H., \& Evans, S. (2011). Choosing an appropriate pronunciation model for the ELT classroom: A Hong Kong perspective. Journal of Asia TEFL.

Cohn, A. C., \& Ravindranath, M. (2014). Local languges in Indonesia: Language maintenance or language shift? Linguistik Indonesia, 32(2), 131-148. http://www.mlindonesia.org/images/files/Agustus 2014.pdf\#page $=33$

Conners, T. J., \& Klok, J. Vander. (2016). Language documentation of colloquial javanese varieties *. 2016 Annual Conference of the Canadian Linguistic Association.

Contreras, F. A. M. B. (2018). Perceptual representations in Interlanguage Phonology: subcategorial learning in late-learners with a smaller vowel inventory [University of Manchester]. http://www.fernandabarrientos.cl/thesis.pdf

Cook, V. (1999). Going beyond the Native Speaker in Language Teaching. TESOL Quarterly, 33(2), 185. https://doi.org/10.2307/3587717

Crismore, A., Ngeow, K. Y. hwa, \& Soo, K. S. (1996). Attitudes toward English in Malaysia. World Englishes. https://doi.org/10.1111/j.1467-971X.1996.tb00118.x

Dardjowidjojo, S. (2000). English Teaching in Indonesia. EA Journal.

Dewi, R., Mujiyanto, J., \& Sukrisno, A. (2017). The Influence of Brebes Javanese Dialect toward Students "Pronunciation of English Speech Sounds ( A Case Study in Sman 1 Brebes ). 1st English Language and Literature International Conference (ELLiC), 189-199.

Edwards, R., \& Holland, J. (2013). What is Qualitative Interviewing? In 
What is Qualitative Interviewing? Bloomsbury Academic. https://doi.org/10.5040/9781472545244

Fadillah, R. (2014). Learning motivation and English achievement of students at politeknik Negeri semarang Central Java. Jurnal Penelitian Humaniora, 15(2), 89-98.

Farrell, T. S. C., \& Martin, S. (2009). To Teach Standard English or World Englishes? A Balanced Approach to Instruction. English Teaching Forum, 2, 2-7.

Flege, J. E. (1988). Factors affecting degree of perceived foreign accent in English sentences. Journal of the Acoustical Society of America. https://doi.org/10.1121/1.396876

Friedlander, P. (2011). Learning languages as expressions of cultures. Electronic Journal of Foreign Language Teaching, 8, 300-311.

Hamied, F. A. (2012). English in Multicultural and Multilingual Indonesian Education. In A. Kirkpatrick \& R. Sussex (Eds.), English as an international language in Asia: Implications for language education (pp. 63-78). https://doi.org/10.1007/978-94-007-45780_5

Hidayat, A. F. (2006). Ensiklopedia bahasa-bahasa, peristilahan dalam bahasa. Pustaka Grafika.

Holmes, J. (2013). An Introduction to Sociolinguistics. In An Introduction to Sociolinguistics. Routledge. https://doi.org/10.4324/9781315833057

Inal, S., \& Turhanl, I. (2005). Teachers' opinions on the use of L1 in EFL classes. Journal of Language and Linguistic Studies, 1(1), 861-875. https://doi.org/10.17263/jlls.631526

Kachru, B. (1992). World Englishes: approaches, issues and resources. Language Teaching, 25(1), 1-14. https://doi.org/10.1017/S0261444800006583

Kachru, Y. (2008). Cultures, Contexts, and World Englishes. In Cultures, Contexts, and World Englishes. Routledge. 
https://doi.org/10.4324/9780203891346

Kioko, A. N., \& Muthwii, M. (2003). English variety for the public domain in kenya: Speakers' attitudes and views. Language, Culture and Curriculum. https://doi.org/10.1080/07908310308666662

Kirkpatrick, Andy. (2011). English as an Asian lingua franca and the multilingual model of ELT. Language Teaching, 44(2), 212-224. https://doi.org/10.1017/S0261444810000145

Kirkpatrick, Andy, \& Liddicoat, A. J. (2017). Language education policy and practice in East and Southeast Asia. Language Teaching, 50(2), 155-188. https://doi.org/10.1017/S0261444817000027

Komariah, A. (2018). Problems in Pronouncing the English Sounds Faced by the Students of SMPN. Journal of English Language and Pedagogy, 1(2), 1-10.

Kosasih, M. M. (2017). Native Language Interference in Learning English Pronunciation: A Case Study at a private university in West Java, Indonesia. International Journal of Education and Research, 5(2), 135-150. https://www.ijern.com/journal/2017/February2017/11.pdf

Krashen, S. (2013). Second Language Acquisition: Theory, Applications, and Some Conjectures. In Mexico City: Cambridge University.

Lamb, M., \& Coleman, H. (2008). Literacy in English and the transformation of self and society in Post-Soeharto Indonesia. International Journal of Bilingual Education and Bilingualism. https://doi.org/10.2167/beb493.0

Lee, K. Y. (2012). Teaching intercultural english learning/teaching in world englishes: Some classroom activities in South Korea. English Teaching, 11(4), 190-205. http://education.waikato.ac.nz/research/files/etpc/files/2012v11 n4nar2.pdf

Li, D. C. S. (2009a). Researching non-native speakers' views toward intelligibility and identity: Bridging the gap between moral high grounds and down-to-earth concerns. In English as an International 
Agus Husein As Sabiq: Localized English for Ngapak Javanese Speakers as Language Instruction| 109

Language: Perspectives and Pedagogical Issues. https://doi.org/10.21832/9781847691231-008

Li, D. C. S. (2009b). Researching non-native speakers' views toward intelligibility and identity: Bridging the gap between moral high grounds and down-to-earth concerns. English as an International Language: Perspectives and Pedagogical Issues, January, 81-118. https://doi.org/10.21832/9781847691231-008

Marefat, F., \& Nushi, M. (2012). Combating Fossilization through Feedback: Does it Work? Fahimeh Marefat. 15(1), 43-71.

Mareva, R., Kaburise, P. K., \& Klu, E. K. (2016). Teaching 'Standard English' or local, code-switched New Englishes in schools in 'Outer Circle' countries? Insights from selected secondary school teachers of English in Zimbabwe. IRA International Journal of Education and Multidisciplinary Studies (ISSN 2455-2526), 4(1), 113-124. https://doi.org/10.21013/jems.v4.n1.p13

Melchers, G., \& Shaw, P. (2011). World Englishes. An Introduction. In English language series.

Moedjito, M. (2008). Priorities in English Pronunciation Teaching in EFL Classrooms. Kata Petra, 10(02), 129-142.

Morganna, R. (2019). Indonesian EFL Teacher's Ideologies of Lingua Culture. ENGLISH FRANCA : Academic Journal of English Language and Education, 3(01), 15. https://doi.org/10.29240/ef.v3i01.630

Njeru, M. G. (2013). Dialect and the Learning of English as a Second Language in Kenya. English Linguistics Research, 2(1), 128-133. https://doi.org/10.5430/elr.v2n1p128

Olatunji, S. (2012). English Language Teachers' Attitudes to the Promotion of the Standard Nigerian English: A Survey from a Nigerian City. African Research Review. https://doi.org/10.4314/afrrev.v6i3.20

Ozen, S. O. (2017). The effect of motivation on student achievement. The Factors Effecting Student Achievement: Meta-Analysis of Empirical Studies, 4(1), 35-56. https://doi.org/10.1007/978-3-319-56083- 
0_3

Pablo, I. M., Lengeling, M. M., Zenil, B. R., Crawford, T., \& Goodwin, D. (2011). Students and Teachers' Reasons for Using the First Language Within the Foreign Language Classroom (French and English) in Central Mexico. PROFILE Issues in Teachers' Professional Development Journal, 13(02). http://www.scielo.org.co/pdf/prf/v13n2/v13n2a09.pdf

Patton, M. (1990). Qualitative Evaluation and Research Methods. In Qualitative Evaluation and Research Methods. https://doi.org/10.1002/nur.4770140111

Pranita, D. (2014). Teacher's Corrective Feedback on Students' Spoken Errors in an EFL Classroom. The 61th TEFLIN International Conference, 61, 1127-1130.

Pranowo, J. (2006). Word-Attack Skills for Indonesian Learners. TEFLIN, 17(2), 107-114.

http://journal.teflin.org/index.php/journal/article/download/63/ 59

Prastiwi, Y. (2013). Transmitting Local Cultural Knowledge through English as Foreign Language (EFL) Learning as a Means of Fostering "Unity in Diversity." Academic Journal of Interdisciplinary Studies. https://doi.org/10.5901/ajis.2013.v2n3p507

Purnama, Y. (2018). The Influence of the First Language to English Performance of EFL Learners The Influence of The First Language to English Performance of EFL Learners of IAIN Purwokerto. ELITE JOURNAL: Journal of English Linguistics, Literature, and Education, 1(1), 2850-9938. www.journal.elitenglish.org

R. Belibi, P. (2013). Teaching a Standard Variety of English or a Local Standard: The Case of Cameroon. International Journal of English Language Education, 1(3), 172-185. https://doi.org/10.5296/ijele.v1i3.3956

Reiter, B. (2017). Theory and Methodology of Exploratory Social Science Research. International Journal of Science and Research 


\section{Methodology.}

Richards, J. C. (2011). Longman Dictionary of Language Teaching and Applied Linguistics. In Longman Dictionary of Language Teaching and Applied Linguistics (4th Editio). Routledge. https://doi.org/10.4324/9781315833835

Rosser, A. (2018). Beyond Access: Making Indonesia's Education Work. In Lowy Institute For International Policy. https://thinkasia.org/handle/11540/8034

Sabiq, A., Purnama, Y., \& Mulyadi, D. (2019). Pedagogical-culture Implementation in English Classroom of Islamic Boarding School. Proceedings of the 2nd Workshop on Language, Literature and Society for Education. https://doi.org/10.4108/eai.21-122018.2282773

Safnil. (2013). A Genre-Based Analysis on The Introductions of Research Articles Written by Indonesian Academics. TEFLIN Journal, 24(2), 180-200.

https://doi.org/http://dx.doi.org/10.15639/teflinjournal.v24i2/18 $0-200$

Shuchi, S. (2013). The Effect of Bangla dialect on English Language Teaching: Teachers 'Perspectives and Attitudes The Effect of Bangla dialect on English Language Teaching: Teachers 'Perspectives and Attitudes Submitted By:

Soedjito. (1986). Pemakaian bahasa Jawa di pesisir utara Jawa Timur bagian sempit (pp. xviii, 110 p.). Pusat Pembinaan dan Pengembangan Bahasa, Departemen Pendidikan dan Kebudayaan. file://catalog.hathitrust.org/Record/000833579

Stebbins, R. (2012). Exploratory Research in the Social Sciences. In Exploratory Research in the Social Sciences. https://doi.org/10.4135/9781412984249

Subandowo, D. (2017). The Language Interference in English Speaking Ability for EFL Learners. The Fifth International Seminar on English Language and Teaching (ISELT-5), 205-210. 
Sudartini, S. (2012). Inserting Local Culture in English Language Teaching To Promote. Pendidikan Karakter, 01(1), 45-54. https://doi.org/10.21831/JPK.V0I1.1451

Suharsih, S. (2017). The Use of Banten-Dialect Javanese Language as the Identity Marker of Banten Society Viewed from Gender Perspective. IJELTAL (Indonesian Journal of English Language Teaching and Applied Linguistics). https://doi.org/10.21093/ijeltal.v1i2.17

Sukarno, S. (2010). The Reflection of the Javanese Cultural Concepts in the Politeness of Javanese. K@ta. https://doi.org/10.9744/kata.12.1.59-71

Swedberg, R. (2018). On the uses of exploratory research and exploratory studies in social science. In Producing Knowledge (pp. 1-37).

Syahri, I., \& Susanti, R. (2016). An Analysis of Local and Target Culture Integration in the English Textbooks for Senior High School in Palembang. Journal of Education and Human Development, 5(2), 97102. https://doi.org/10.15640/jehd.v5n2a11

Tegegne, W. (2015). The Use of Dialects in Education and Its Impacts on Students' Learning and Achievements. Education Journal, 4(5), 263. https://doi.org/10.11648/j.edu.20150405.22

Thornbury, S. (2013). Essential Teacher Knowledge. ELT Journal, 67(1), 131-133. https://doi.org/10.1093/elt/ccs075

Tiono, N. I., \& Yosta, A. M. (2008). a Study of English Phonological Errors Produced By English Department Students. K@Ta, 10(1), 79-112. https://doi.org/10.9744/kata.10.1.79-112

Tollefson, J. W. (2012). Reconsidering “Target Language.” Language Research Bulletin, 17, 143-152.

Wardhana, D. E. C., \& Apriani, E. Maxim Variation, Conventional, and Particularized Implicature on Students' Conversation.

Yuliati, Y. (2014). Final Consonant Clusters Simplification by Indonesian Learners of English and Its Intelligibility in International Context. 
Agus Husein As Sabiq: Localized English for Ngapak Javanese Speakers as Language Instruction| 113

International Journal of Social Science and Humanity, 4(6), 513-517. https://doi.org/10.7763/ijssh.2014.v4.409

Yulika, R., Rahman, U., \& Sewang, A. M. (2019). The Effect of Emotional Intelligence and Learning Motivation on Student Achievement. 39(1), 1-8. https://doi.org/10.2991/icamr-18.2019.94

Zulfikar, T. (2018). The Making of Indonesian Education: An overview on Empowering Indonesian Teachers. Journal of Indonesian Social Sciences and Humanities, 2, 13-39. https://doi.org/10.14203/jissh.v2i0.19 
114 | ENGLISH FRANCA, Vol. 4, No. 2, 2020

EMPTY PAGE 